\title{
VERTEBRATE AIR BREATHING AROSE IN FRESH WATERS AND NOT IN THE OCEANS
}

\author{
Jefrrey B. Graham, ${ }^{1}$ Richard H. Rosenbtatt, and Carl Gans \\ Smithsonian Tropical Research Institute, Balboa, Canal Zone, Scripps Institution of Oceanography, \\ La Jolla, California, and Department of Zoology, University of Michigan, Ann Arbor
}

Received December 13, 1976. Revised July 27, 1977

Packard (1974) recently suggested, in contrast to the consensus of opinion, that the evolution of air breathing in the early fishes most probably occurred in forms inhabiting seawater. He noted the much discussed occurrence of some Silurian gnathostome fossils in marine deposits (Romer, 1966, 1968; Thomson, 1969, 1971) and supported his argument with references to the known differences in $\mathrm{O}_{2}$ solubility of fresh and salt water as well as to recent studies on the respiratory physiology of fishes. His argument was that conditions requisite for the evolution of air breathing existed in saltwater habitats, such as enclosed hypersaline estuaries and lagoons.

A review of his suggestions indicates that the evidence does not support them. While some marine fishes breathe air, the marine environment is and probably was an exceptional one for these adaptations. Consequently, we question the concept that air breathing (1) arose in salt water or (2) represents a response to the higher density and lower $\mathrm{O}_{2}$ solubility of that medium. The several counter-arguments are summarized below.

\section{Does the $\mathrm{O}_{2}$ Concentration of Seawater Impose a Severe Pumping Load?}

The solubility of $\mathrm{O}_{2}$ is inversely proportional to the salinity of water; thus, and depending upon temperature, air-equilibrated fresh water contains about $25-30 \%$ more $\mathrm{O}_{2}$ than water with a salinity of 35\% (Randall, 1970). Packard used this observation to argue that marine fishes historically have had to deal with an environment which is relatively hypoxic compared to that of freshwater fishes. He concluded that a marine fish must expend 25-30\% more energy for gill ventilation ... (Packard, Table 3 ) in order to obtain the same amount of $\mathrm{O}_{2}$ as a freshwater fish.

Is seawater sufficiently deoxygenated to impose energetically prohibitive limits on fish ventilation? Estimates of the metabolic cost of gill ventilation vary but using a value recently ob-

${ }^{1}$ Present address: Department of Zoology, San Diego State University, San Diego, California 92182. tained for freshwater fishes $(10 \%$ of standard $\mathrm{O}_{2}$ consumption; Hughes, 1973), we have charted the probable allocation of $\mathrm{O}_{2}$ to gill ventilation and other oxidative processes in hypothetical salt- and freshwater fishes (Table 1; based on Packard's data). Assuming that the freshwater fish uses $10 \%$ of its metabolic rate for the acquisition of $\mathrm{O}_{2}$ and that gill ventilation requires as much as $30 \%$ more energy on the part of the saltwater fish, then the latter would only be deficient by $3 \%$ in terms of supplying $\mathrm{O}_{2}$ for its metabolic processes. In other words, it would have to increase its overall rate by that amount to maintain other functions. The ventilation efficiency might also decrease with the increase of ventilation forced by the lower $\mathrm{O}_{2}$ content of seawater, and this could produce a disproportionately high caloric cost. However, even if the cost is doubled, the maximum reduction in the $\mathrm{O}_{2}$ available to other tissues is only $11 \%$.

The foregoing considerations indicate that only a slight adjustment of metabolic rate is needed to enable a fish to respire in seawater. Airequilibrated seawater, although containing quantitatively less dissolved $\mathrm{O}_{2}$ than fresh water, has the same partial pressure of $\mathrm{O}_{2}\left(\mathrm{PO}_{2}\right.$; about 150 torr at 1 atmosphere). The $\mathrm{PO}_{2}$ of water directly affects diffusion rate and thus is a more important consideration, in terms of $\mathrm{O}_{2}$ transfer at the gill surface, than is the $\mathrm{O}_{2}$ content (Dejours, $1975)$. The estimated $3 \%$ to $11 \%$ deficiency in $\mathrm{O}_{2}$ uptake that a marine fish might experience could be overcome by simply absorbing more $\mathrm{O}_{2}$ from water passing over the gills.

Probably this deficiency is too small to establish a selective advantage sufficient to lead to the evolution of air breathing. Fishes such as eels and salmon migrate to and from salt water, apparently without encountering major limitations in their gill-ventilatory capability, although compensatory changes in hemoglobin- $\mathrm{O}_{2}$ affinity do take place (Vanstone et al., 1964; Kaloustian and Poluhowich, 1976). There are a number of well-documented, long- and short-term respiratory adaptations of fishes (viz., changes in ventilation pattern, gill area or gill geometry; increased hemoglobin- $\mathrm{O}_{2}$ affinity) that could be invoked to increase $\mathrm{O}_{2}$ utilization by the required 
TABLE 1. Comparison of the metabolic cost of gill ventilation and other oxidative processes in hypothetical fresh- and saltwater fishes. It is assumed that both fish have the same standard $O_{2}$ uptake rate and that branchial ventilation requires $10 \%$ of $\mathrm{O}_{2}$ uptake for the freshwater fish but is $30 \%$ higher for the saltwater fish. Standard $\mathrm{O}_{2}$ consumption rates are from Packard (1974); units are $m l / g / h$.

\begin{tabular}{lcc}
\hline \hline & $\begin{array}{c}\text { Freshwater } \\
\text { fish }\end{array}$ & $\begin{array}{c}\text { Saltwater } \\
\text { fish }\end{array}$ \\
\hline $\begin{array}{l}\text { Standard } \mathrm{O}_{2} \text { consumption } \\
\mathrm{O}_{2} \text { used for gill } \\
\text { ventilation (10\%) }\end{array}$ & 0.169 & 0.169 \\
$\begin{array}{l}\text { Additional } \mathrm{O}_{2} \text { used for } \\
\text { gill ventilation }\end{array}$ & 0.017 & 0.017 \\
$\quad$ in seawater (30\%) & - & 0.005 \\
$\begin{array}{l}\text { Total ventilatory cost } \\
\text { Net } \mathrm{O}_{2} \text { remaining } \\
\text { for other processes }\end{array}$ & 0.017 & 0.022 \\
$\begin{array}{l}\mathrm{O}_{2} \text { deficiency* of seawater }(\%) \\
\text { * } 100-\left(\frac{0.147}{0.152} \times 100\right)\end{array}$ & 0.152 & 0.147 \\
$\quad \begin{array}{l}\text { or, increased } \mathrm{O}_{2} \text { uptake required to maintain other } \\
\text { processes: } \\
\left(\frac{0.174}{0.169} \times 100\right)-100=2.95 \cong 3 \% .\end{array}$
\end{tabular}

amount (Hughes, 1960, 1973; Srivastava and Griffith, 1974). These would, in our opinion, supercede, both in selective advantage and efficacy, the evolution of air breathing in salt water through "an aberrant behavior pattern involving gulping at the surface" (Packard, 1974, p. 323).

But, under what circumstances would a marine fish encounter a situation in which some of its population started to gulp air? Ventilation cost is probably not monitored on the short time span and even an $11 \%$ increase should not be physiologically significant over a short time course. Blood $\mathrm{PO}_{2}$ is monitored by fishes and, along with other properties, controls respiration; however, only large reductions in ambient $\mathrm{PO}_{2}$ are likely to affect blood $\mathrm{O}_{2}$ level sufficiently to cause compensation (Shelton, 1970). Observations show that low ambient $\mathrm{PO}_{2}$ can drive fishes to the surface (Breder, 1941). This can easily be visualized as leading to early stages of bubble pickup (Gans, 1970). Air-breathing fishes, both freshwater and estuarine (Graham, 1976), breathe air in response to anoxia rather than to reduced $\mathrm{O}_{2}$ solubility (see below).

\section{Conditions in StuURtan SEAS}

Large and somewhat isolated bodies of seawater were common in the Silurian Period
(Moore, 1958, p. 178). Packard likened these to estuaries, the physical characteristics of which he used as a model in speculating about physical conditions. He postulated that elevated temperature and hypersalinity may have been common conditions in tropical and subtropical bodies of water that were cut off from the ocean. Both of these conditions reduce $\mathrm{O}_{2}$ content and the former raises $\mathrm{O}_{2}$ demand. Together with the ventilatory limitations initially imposed by salt water, these were, in Packard's opinion, a primary factor leading to the evolution of air breathing.

This hypothesis does not give adequate weight to the probability that early fishes could have adapted to elevated temperatures by adjusting their metabolic rate and thus reducing the temperature effect on ventilation requirements (as indicated in Packard's Table 1; Fry, 1971; Holeton, 1974). Other compensatory adjustments in $\mathrm{O}_{2}$ utilization (e.g., changes in hemoglobin- $\mathrm{O}_{2}$ affinity, and heart rate; Grigg, 1969; Randall, 1970) would also reduce this continuous effect. Packard emphasized the importance of low $\mathrm{O}_{2}$ concentrations, resulting from changes in physical conditions affecting $\mathrm{O}_{2}$ solubility; a major complication derives from the influence of anoxic conditions caused principally by biological oxygen demand. This lowers $\mathrm{PO}_{2}$ and, if not balanced by diffusion from the atmosphere, may result in anoxia. Anoxia does occasionally occur in parts of some estuaries, but is far more commonly a phenomenon of tropical freshwater swamps, pools and streams. Anoxia, moreover, is a more frequent cause of fish kills in estuaries than are changes in $\mathrm{O}_{2}$ solubility (Biggs, 1967; McHugh, 1967; Green, 1968). Recent fishes of tropical waters are generally thought to breathe air in order to enable them to endure such biologically caused anoxic conditions (Gans, 1970; Johansen, 1970).

Several additional reasons suggest it is unlikely that air breathing evolved in Silurian seas. First, salinity and temperature are significant environmental variables that directly affect aquatic species, with high temperature acting on factors such as metabolism, and hypersalinity acting on osmotic functions. The combined and probably synergistic effects would likely pose direct problems long before eliciting possible effects on respiration through a reduction of $\mathrm{O}_{2}$ solubility. For example, the above-mentioned biotic respiration in a stagnant freshwater swamp can easily remove over $90 \%$ of the $\mathrm{O}_{2}$ (Kramer and Graham, 1976), lowering the $P_{2}$ to about 15 torr, while a $32 \mathrm{C}$ increase in temperature combined with a $9 \%$ increase in salinity only changes the $\mathrm{O}_{2}$ content of seawater by $50 \%$ (Sverdrup et al., 1964, p. 188), leaving the $\mathrm{PO}_{2}$ near about 150 torr.

Such typically estuarine forms as cyprinodonts and mullet have physiological adaptations both for varying temperature and salinity (Green, 
1968) but none known that permit aerial respiration. Also, the modern air-breathing species oppose rather than support the hypothesis for the estuarine-evolution of air breathing. The vast majority of air-breathing fishes occur in fresh waters (Gans, 1970; Roberts, 1975). The vast majority of marine air-breathing fishes occur in oxygenated intertidal zones and only breathe air while amphibious or when exposed during low tide. Only a few species are estuarine and, as indicated above, these breathe air primarily in response to low $\mathrm{PO}_{2}$ (Graham, 1976).

It is also worth noting that not all Silurian coastal waters were hypersaline, but that they varied in salinity with some being brackish (Cocks and McKerrow, 1973). A number of characteristic Silurian evaporite deposits contain either a low diversity or no fossils (Moore, 1958). This implies that hypersaline conditions were localized, irregular, and in some regions became progressively more severe, leading to ecological instability, low species diversity, and, ultimately, to extinctions; none of these conditions would seem to favor successful adaptatons for air breathing. By contrast, the "freshwater evolution" of air breathing is thought to have occurred as an adaptation for conditions such as the regular tropical dry seasons which have a widespread effect and result in variable drying, but generalized seasonal stagnation, and anoxia in the shaded, wind-protected, freshwater streambeds and swamps (Carter and Beadle, 1931; Gans, 1970; Johansen, 1970).

\section{Metabolic Scope}

An additional aspect of Packard's hypothesis is the increased metabolic scope associated with air breathing. Several air-breathing fishes have higher rates of $\mathrm{O}_{2}$ consumption when respiring bimodally (simultaneously in air and water) than when breathing in water only (Grigg, 1965; Hughes and Singh, 1970, 1971). Packard suggested that air breathing allowed ancient fishes competitive superiority by expanding their metabolic scope above that of non-air breathers. Although this suggestion is attractive, it is not supported by the evidence. Packard stated (p. 322) "oxygen requirements of resting (airbreathing) fishes generally can be satisfied by aquatic respiration, but they make regular visits to the surface while foraging or swimming actively." This, although accurate for a few species (Grigg, 1965; Johansen, 1970), does not apply to most. For example, facultative air breathers only use their capability when water is an unsuitable respiratory medium and obligate air breathers must continually breathe air, regardless of activity level or water conditions (Carter, 1957). Both activity and physical factors $\left(\mathrm{PO}_{2}\right.$, $\mathrm{PCO}_{2}, \mathrm{pH}$, and temperature) influence the rate of air breathing (Grigg, 1965; Johansen, 1970; Horn and Riggs, 1973 and references).

If the initial stages of air breathing provided an effective increase of metabolic scope under other than near-anoxic conditions, we might expect to find it to be widespread among fishes. However, except for Neoceratodus and marine intertidal species, which breathe air only when they are out of water, air-breathing fishes experience hypoxic stress periodically, or at some stage in their life histories. Neoceratodus is really exceptional. Air breathing enables it to increase its metabolic rate (Grigg, 1965). However, as Grigg has cogently argued, this is not the factor that influenced the initial evolution of the lung. Many air-breathing fishes have reduced gill area and use gills mainly for $\mathrm{CO}_{2}$ discharge (see review by Packard, 1976). Air breathing may enable these forms to maintain a high level of $\mathrm{O}_{2}$ consumption without adding gill area which would elevate the energetic cost (of ventilation) (Grigg, 1965).

\section{Conclusions}

Packard has succinctly reviewed the arguments in favor of a freshwater origin of air breathing in early fishes. He has not attempted to negate this widely-held concept but has instead attempted to provide a viable alternative hypothesis not requiring a freshwater sojourn and to argue that it represents a more probable scenario for this set of events. However, the supporting arguments at best plead a special case for the evolution of air breathing in a marine or estuarine environment. We suggest that there is not sufficient basis for arguing that the lower solubility of $\mathrm{O}_{2}$ in seawater imposed important ventilatory limitations on marine fishes and, therefore, was a driving force in the evolution of air breathing. Similarly, the extreme salinity and temperature conditions required in the marine origin hypothesis to reduce water- $\mathrm{O}_{2}$ solubility in estuaries sufficiently to cause respiratory stress and result in the evolution of air breathing, would have probably been lethal to most populations living in such environments before respiratory patterns were modified. The suggestion that increased metabolic scope was an important factor in the development of air breathing, while feasible, is not consistent with the manner in which most extant air-breathing species utilize this capability. The majority of Recent air-breathing species occupy habitats that become hypoxic, and there are none that appear to have developed air breathing solely to increase metabolic scope apart from the presence of a hypoxic stress. The key point is that air breathers are able to endure hypoxic conditions, and thus can live in waters subject to extreme fluctuations in $\mathrm{O}_{2}$ level. The capacity to survive critical times, rather than a 
minor but continuous energy cost, is much more likely to have driven the transition to air breathing.

\section{ACKNOWLEDGMENTS}

We thank B. Clark, R. Estes, D. L. Kramer, H. T. Hammel, and K. S. Thomson for critically reviewing the manuscript and offering valuable suggestions for improvement This work was supported by grants from the Smithsonian Research Foundation (SRF 71702106) and from NSF (DEB 76 19289).

\section{Literature Cited}

BigGs, R. B. 1967. The sediments of Chesapeake Bay, p. 239-260. In G. H. Lauff (ed.), Estuaries. Amer. Assoc. Adv Sci, Washington, $757 \mathrm{p}$.

BREDER, C. M. 1941. Respiratory behavior in fishes not especially modified for breathing air under conditions of depleted oxygen. Zoologica 26:243-244.

Carter, G. S. 1957. Air breathing, p. 65-79. In M. E. Brown (ed.), The Physiology of Fishes. Vol. I. Academic Press, New York, $447 \mathrm{p}$.

Carter, G. S., and L. C. Beadle. 1931. The fauna of the swamps of the Paraguayan Chaco in relation to its environment. II. Respiratory adaptations in the fishes. J. Linn. Soc. Lond. (Zool.) 37:327-368.

Cocks, L. R. M., and W. S. McKerrow. 1973. Brachiopod distribution and faunal provinces in the Silurian and lower Devonian, p. 291305. In N. F. Hughes (ed.), Organisms and Continents through Time. Spec. Pap. Paleont. 12:291-305.

Dejours, P. 1975. Principles of Comparative Respiratory Physiology. North Holland, $\mathrm{Ox}$ ford, $253 \mathrm{p}$.

FRY, F. E. J. 1971. The effect of environmental factors on the physiology of fish, p. 1-98. In W. S. Hoar and D. J. Randall (eds.), Fish Physiology. Vol. VI. Academic Press, New York, $559 \mathrm{p}$.

GaNs, C. 1970. Strategy and sequence in the evolution of the external gas exchangers of ectothermal vertebrates. Forma et Functio 3:61-104

GrahaM, J. B. 1976. Respiratory adaptations of marine air breathing fishes, p. 165-187. In G. M. Hughes (ed.), Respiration of Amphibious Vertebrates. Academic Press, New York and London, 402 p.

Green, J. 1968. The Biology of Estuarine Animals. Univ. Washington, Seattle, 401 p.

GrIGG, G. C. 1965. Studies on the Queensland lungfish, Neoceratodus forsteri (Krefft). III.
Aerial respiration in relation to habits. Austral. J. Zool. 13:413-421.

- 1969. Temperature-induced changes in the oxygen equilibrium curve of the blood of the brown bullhead, Ictalurus nebulosus. Comp. Biochem. Physiol. 28:1203-1223.

Holeton, G. F. 1974. Metabolic cold adaptations of polar fish: Fact or artefact. Physiol. Zool. 47:137-152.

Horn, M. H., AND C. D. Riggs. 1973. Effects of temperature and light on the rate of air breathing of the bowfin, Amia calva. Copeia 1973:653-657.

Hughes, G. M. 1960. A comparative study of gill ventilation in teleosts. J. Exp. Biol. 37: $28-45$.

- 1973. Respiratory responses to hypoxia in fish. Amer. Zool. 13:475-489.

Hughes, G. M., ANd B. N. Singh. 1970. Respiration in an air-breathing fish, the climbing perch Anabas testudineus Bloch. I. Oxygen uptake and carbon dioxide release into air and water. J. Exp. Biol. 53:265-280.

- 1971. Gas exchange with air and water in an air-breathing catfish Saccobranchus fossilis. J. Exp. Biol. 55:667-682.

JohANSEN, K. 1970 . Air breathing in fishes, $p$. 361-411. In W. S. Hoar and D. J. Randall (eds.), Fish Physiology. Vol. IV. Academic Press, New York, 532 p.

Kaloustlan, K. V., and J. J. Poluhowich. 1976. The role of organic phosphates in modulating the oxygenation behavior of eel haemoglobin. Comp. Biochem. Physiol. 53A: $245-248$.

Kramer, D. L., and J. B. Graham. 1976. Synchronous air breathing, a social component of respiration in fishes. Copeia 1976:689-697.

McHugr, J. L. 1967. Estuarine nekton, p. 581-620. In G. H. Lauff (ed.), Estuaries. Amer. Assoc. Adv. Sci., Washington, 757 p.

Moore, R. C. 1958. Introduction to Historical Geology. Second edition. McGraw Hill, New York, $656 \mathrm{p}$.

PACRARD, G. C. 1974. The evolution of airbreathing in paleozoic gnathostome fishes. Evolution 28:320-325.

—_ 1976. Devonian amphibians: Did they excrete carbon dioxide via skin, gills, or lungs? Evolution 30:270-280.

Randall, D. J. 1970. Gas exchange in fish, p. 253-292. In W. S. Hoar and D. J. Randall (eds.), Fish Physiology. Vol. IV. Academic Press, New York, 532 p.

RoberTs, T. R. 1975. Geographical distribution of African freshwater fishes. Zool. J. Linnean Society 57:249-319.

Romer, A. S. 1966. Vertebrate Paleontology. Third edition. Univ. Chicago Press, Chicago, 468 p.

—_. 1968. Notes and Comments on Verte- 
brate Paleontology. Univ. Chicago Press, Chicago, $304 \mathrm{p}$.

SheltoN, G. 1970. The regulation of breathing, p. 293-359. In W. S. Hoar and D. J. Randall (eds.), Fish Physiology. Vol. IV. Academic Press, New York, 532 p.

Srivastava, A. K., and R. W. Griffith. 1974. Erythrocyte morphology and the ecology of species of Fundulus. Copeia 1974:136-141.

SverdruP, H. V., M. Johnson, and R. Fleming. 1964. The Oceans: Their Physics, Chemis- try, and General Biology. Prentice Hall, New Jersey, 1087 p.

Thomson, K. S. 1969. The biology of the lobefinned fishes. Biol. Rev. 44:91-154.

- 1971. The adaptation and evolution of early fishes. Quart. Rev. Biol. 46:139-166.

Vanstone, W. E., E. Roberts, and H. Tsuyuki. 1964. Changes in the multiple hemoglobin patterns of some Pacific salmon, genus Oncorhynchus during the parr-smolt transformation. Can. J. Physiol. Pharmacol. 42:697-703. 